\title{
ANALISIS PENGARUH PERTUMBUHAN ASET, UKURAN PERUSAHAAN, PROFITABILITAS DAN RISIKO BISNIS TERHADAP STRUKTUR MODAL SUB SEKTOR KOSMETIK DAN KEPERLUAN RUMAH TANGGA
}

\author{
Birgita Maryeta Naur ${ }^{1}$ danMoch. Nafi' ${ }^{2}$ \\ ${ }^{1,2}$ Fakultas Ekonomi dan Bisnis Universitas Merdeka Malang \\ birgitayeta@gmail.com
}

\begin{abstract}
The purpose of this study was to examine the effect of asset growth, firm size, profitability and business risk simultaneously on the capital structure. The population of this study are manufacturing companies subsectors of food and beverages listed on the Stock Exchange during 2010-2015. The total number of samples is 5 companies. The sampling technique used was purposive sampling. The method of data analysis that uses regression and statistical description. The size of the company, Profitability and the business risk is partially not significantly affect the capital structure. Asset growth has a significant effect on the capital structure partially. Simultaneously variable firm size, profitability, asset growth and business risk significant influence terhasap capital structure. The results showed of four independent variables, firm size, profitability and business risk significantly affect the capital structure is simply asset growth. The three others variable despite having influence, but not significant. Raise capital to take advantage of outside capital into opportunities that can be used see the low risk businesses owned most of the companies manufacturing subsectors of cosmetics and household use.
\end{abstract}

Keywords: firm size, profitability, asset growth, business risk, capital structure

\section{PENDAHULUAN}

Struktur modal secara sederhana dapat dikatakan sebagai perbandingan jumlah modal perusahaan antara modal yang diperoleh dari internal perusahaan (modal sendiri) atau modal yang diperoleh dari eksternal perusahaan (hutang). Perbandingan yang tepat (optimal) menjadikan kebijakan-kebijakan yang diambil perusahaan ke depannya akan membuat risiko perusahan semakin kecil dan peluang perusahaan memperoleh laba semakin tinggi. "Komposisi hutang dan ekuitas tidak optimal akan mengurangi profitabilitas perusahaan" (Nugroho, 2006), sejalan dengan hal tersebut perbandingan antara modal dan hutang akan mempengaruhi jalannya perusahaan.
Menentukan seberapa besar bagian yang dibutuhkan untuk mengambil modal yang berasal dari internal atau eksternal perusahaan adalah menjadi kebijakan dari manajemen. Melihat rasio-rasio yang bisa diperoleh dari data-data yang ada di dalam Laporan Keuangan, adalah cara manajemen dalam menentukan seberapa besar modal yang diperlukan, juga kebutuhan akan seberapa modal sendiri dan seberapa besar hutang yang akan digunakan.

Struktur modal perusahaan berubah seiring berjalannya perusahaan. Perubahaan pada struktur modal ini adalah karena perubahan berbagai faktor. Menurut Weston dan Brigham (2014) faktor-faktor yang mempengaruhi struktur modal perusahaan 
adalah stabilitas perusahaan, struktur aset, leverage operasi, tingkat pertumbuhan, profitabilitas, pajak, pengendalian, sikap manajemen, sikap pemberi pinjaman dan perusahaan penilai kredibilitas, kondisi internal perusahaan, dan fleksibilitas keuangan perusahan. Penelitian telah banyak dilakukan untuk memastikan faktor-faktor apa yang mempengaruhi struktur modal, diantaranya peneliti oleh Wahyuningsih (2012) memasukkan ukuran perusahaan, tingkat profitabilitas, pertumbuhan penjualan, struktur aset, investasi dan operating leverage sebagai independen terhadap struktur modal sebagai varibel dependennya. Hasil penelitian Wahyuningsih (2012) menunjukan bahwa ukuran perusahaan, tingkat profitabilitas, dan pertumbuhan penjualan berpengaruh signifikan terhadap struktur modal. Sedangkan variabel struktur aset, investasi dan operating leverage tidak signifikan.

Ukuran perusahaan merupakan salah satu faktor yang harus dipertimbangkan dalam keputusan struktur modal. Perusahaan besar memiliki kebutuhan dana yang besar untuk membiayai aktivitas perusahaan dan salah satu alternatif pemenuhan kebutuhan dana tersebut adalah dengan menggunakan hutang. Dengan kata lain, besar kecilnya ukuran suatu perusahaan secara langgsung berpengaruh terhadap kebijakan struktur modal perusahaan. Penelitian terdahulu yang menghubungkan ukuran perusahaan terhadap kebijakan struktur modal perusahaan.

Tingkat profitabilitas suatu perusahaan menjadi salah satu faktor yang dipertimbangkan dalam kebijakan struktur modal. Brigham dan Houston (2004) mengatakan seringkali perusahaan dengan tingkat pengembalian yang tinggi cenderung menggunakan hutang. Tetapi perusahaan dengan tingkat pengembalian yang rendah cenderung menggunakan hutang yang besar untuk membiayai aktivitas perusahaan.

Pertumbuhan aset merupakan variabel yang dipertimbangkan dalam keputusan hutang. Biasanya biaya emisi saham akan lebih besar dari biaya penerbitan surat hutang. Demikian, perusahaan yang tingkat pertumbuhannya lebih tinggi cenderung lebih banyak menggunakan hutang, sehingga ada hubungan positif antara growth dengan debt equity ratio. (Brigham, 2004), perusahaan yang mempunyai tingkat pertumbuhan tinggi cenderung menggunakan sumber dana dari luar. Perusahaan dengan tingkat pertumbuhan yang cepat harus lebih banyak mengandalkan modal eksternal daripada perusahaan yang lambat pertumbuhannya.

Risiko bisnis juga berpengaruh terhadap struktur modal. Risiko bisnis berkaitan dengan ketidakpastian pendapatan karena terdapatnya variabilitas dalam penjualan produk, pelanggan dan bagaimana produk dihasilkan. Ketidakpastian tersebut membuat risiko bisnis yang ada pada perusahaan berubah-ubah, begitu juga dengan struktur modal yang dihasilkan 
bervariasi. Risiko bisnis atau risiko inheren dengan operasi risiko jika perusahaan tidak mempergunakan hutang. Semakin tinggi risiko bisnis perusahaan, maka semakin rendah rasio hutang optimalnya (Sunarwi, 2010).

Ketidak konsistenan pada penelitianpenelitian terdahulu pada masing-masing variabel yang dijadikan sebagai bahan untuk penelitian menunjukan adanya perbedaanperbedaan yang ada pada masing-masing penelitian. Perbedaan-perbedaan tersebut diantaranya adalah perbedaaan tahun penelitian, perbedaan jumlah perusahaan yang menjadi objek, atau perbedaan situasi bahan kaji menarik dalam penelitian, karena dinamisme perekonomian maka menyebabkan setiap saat adalah saat yang tepat untuk dilakukan penelitian, terutama jika terjadi fenomena ekonomi global yang disinyalir juga ikut mempengaruhi perekonomian nasional.

Variabel pertumbuhan aset, ukuran perusahaan, profitabilitas dan risiko bisnis sering digunakan sebagai alat analisis meskipun selalu menunjukan hasil yang tidak konsisten antara peneliti yang satu dengan yang lain, hal ini dikarenakan variabel-variabel tersebut belum adanya teori yang melemahkan teori lama yang menunjukkan bahwa variabel-variabel tersebut adalah faktor yang mempengaruhi variabel stuktur modal.

Berdasarkan latar belakang tersebut diatas, maka permasalahan dalam penelitian ini dapat dirumuskan sebagai berikut: "Apakah pertumbuhan aset, ukuran perusahaan, profitabilitas dan risiko bisnis berpengaruh terhadap struktur modal."

Tujuan penelitian ini adalah menguji pengaruh ukuran perusahaan, profitabilitas, pertumbuhan aset dan risiko bisnis simultan terhadap struktur modal.

\section{TINJAUAN PUSTAKA}

\section{Terori struktur modal}

Laporan keuangan perusahaan terdiri dari sisi aset yang mencerminkan struktur kekayaan dan sisi pasiva sebagai struktur keuangan. Struktur modal sendiri merupakan bagian dari struktur keuangan yang dapat diartikan sebagai pembelanjaan permanen yang mencerminkan perimbangan antara hutang jangka panjang dengan modal sendiri.

Menurut Weston dan Brigham (2014) struktur keuangan adalah cara bagaimana perusahaan membiayai aktivanya dan dapat dilihat pada seluruh sisi kanan dari neraca yang terdiri dari hutang jangka pendek, hutang jangka panjang dan modal pemegang saham. Sedangkan struktur modal perusahaan adalah pembiayaan permanen yang terdiri dari hutang jangka panjang, saham preferen dan modal pemegang saham. Jadi, struktur modal suatu perusahaan hanya merupakan sebagian dari struktur keuangannya. Sedangkan menurut Van Horne dan Wachowicz (2013) struktur modal adalah bauran (proporsi) pendanaan permanen jangka panjang perusahaan yang ditunjukkan oleh hutang, ekuitas saham preferen dan saham biasa. 
Teori struktur modal menjelaskan apakah ada pengaruh perubahan struktur modal terhadap nilai perusahaan (yang tercermin dari harga saham perusahaan), kalau keputusan investasi dan kebijakan deviden dipegang konstan. Dengan kata lain, seandainya perusahaaan mengganti sebagian modal sendiri dengan hutang (atau sebaliknya) apakah harga saham akan berubah, apabila perusahaan tidak merubah keputusan-keputusan keuangan lainnya. Dengan kata lain, kalau perubahan struktur modal tidak merubah nilai perusahaan, berarti tidak ada struktur modal yang terbaik. Semua struktur modal adalah baik. Akan tetapi, kalau dengan merubah struktur modal ternyata nilai perusahaan berubah, maka akan diperoleh struktur modal yang terbaik.

Menurut Husnan (2008), teori struktur modal yang optimal adalah suatu struktur dimana biaya riil (marginal real cost) dari masing-masing sumber pembelanjaan adalah sama. Struktur modal yang optimal adalah struktur modal yang meminimumkan biaya modal perusahaan. Dalam prakteknya, sulit untuk memperkirakan apa yang terjadi dengan biaya modal perusahaan kalau perusahaan merubah struktur modalnya.

Agency Theory menurut Horne dan Wachowiez (2007) menyatakan bahwa manajemen merupakan agen dari pemegang saham, sebagai pemilik perusahaan. Para pemegang saham berharap agen akan bertindak atas kepentingan mereka sehingga mendelegasikan wewenang kepada agen. Untuk dapat melakukan fungsi dengan baik, manajemen harus diberi insentif dan pengawasan yang memadai. Pengawasan dapat dilakukan melalui cara-cara seperti pengikatan agen, pemeriksaan laporan keuangan, dan pembatasan terhadap keputusan yang dapat diambil manajemen. Kegiatan pengawasan tentu saja membutuhkan biaya yang disebut dengan biaya agensi. Menurut Horne dan Wachowiez (2007: 482), biaya agensi adalah biaya-biaya yang berhubungan dengan pengawasan manajemen untuk meyakinkan bahwa manajemen bertindak konsisten sesuai dengan perjanjian kontraktual perusahaan dengan kreditor dan pemegang saham.

Trade-off Theory adalah pendekatan umum untuk memahami atau menjelaskan pengambilan keputusan terkait dengan struktur modal dikenal sebagai static trade-off theory. Sebutan tersebut sesuai dengan esensi dimana nilai sekarang (present value) dari manfaat penghematan pajak (tax shield) yang timbul dari peningkatan penggunaan financial leverage mengalami dilema trade-off (Scott, 2011). Biaya bunga dapat mengurangi pajak dalam menghitung pajak yang harus dibayar perusahaan. Dalam hal ini, penggunaan kewajiban akan menghasilkan harga pasar modal yang lebih tinggi bagi sekuritas perusahaan yang beredar. Ketika laba perusahaan dikenai pajak oleh pemerintah, maka jumlah pembayaran kas kepada 
kontributor modal akan dipengaruhi oleh bauran pendanaan perusahaan.

Brigham dan Houston (2011) menjelaskan mengenai ringkasan teori pertukaran (trade-off theory) adalah adanya fakta bahwa bunga yang dibayarkan sebagai beban pengurang pajak membuat hutang menjadi lebih murah dibandingkan dengan saham biasa atau saham preferen. Secara tidak langsung, pemerintah membayar sebagian biaya hutang atau dengan kata lain hutang memberikan manfaat perlindungan pajak.

Pecking Order Theory teori ini pertama kali diajukan oleh Gordon Donaldson pada tahun 1964 sebagai teori yang menjelaskan perilaku keuangan perusahaan. Versi modifikasi dari pecking order theory diajukan oleh Myers (2001), yang mengemukakan:

a. Kebijakan deviden perusahaan bersifat sticky (tidak mudah berubah). Manajer berusaha membagikan deviden dalam jumlah yang konstan meskipun terjadi fluktuasi pada laba perusahaan.

b. Perusahaan lebih menyukai sumber dana internal (seperti laba ditahan dan akumulasi penyusutan) dibandingkan sumber dana eksternal (hutang dan saham).

c. Jika harus memakai sumber dana eksternal, maka prioritas utama yang dipilih perusahaan adalah hutang yang aman (safe debt), kemudian hutang yang berisiko (risky debt), convertible securities, saham preferen dan sebagai prioritas terakhir adalah saham biasa.
Secara ringkas pecking order theory menyatakan bahwa pertama, perusahaan lebih menyukai internal financing (pendanaan dari hasil operasi perusahaan). Kedua, perusahaan mencoba menyesuaikan rasio pembagian deviden yang ditargetkan dengan berusaha menghindari perubahan pembayaran deviden secara drastis. Ketiga, kebijakan dividen yang konstan dengan fluktuasi profitabilitas dan kesempatan investasi yang tidak dapat bisa diduga. Keempat, apabila pendanaan dari luar (external financing) diperlukan, maka perusahaan akan menerbitkan sekuritas paling aman terlebih dahulu (Brealey dan Myers, 2001).

The Modigliani-Miller Theorem adalah teori yang berpandangan bahwa struktur modal tidak relevan atau tidak mempengaruhi nilai perusahaan. MM mengajukan beberapa asumsi untuk membangun teori mereka (Brigham dan Houston, 2001) yaitu: Tidak terdapat agency cost, tidak ada pajak, investor dapat berhutang dengan tingkat suku bunga yang sama dengan perusahaan,investor mempunyai informasi yang sama seperti manajemen mengenai prospek perusahaan di masa depan, tidak ada biaya kebangkrutan, Earning Before Interest and Taxes (EBIT) tidak dipengaruhi oleh penggunaan dari hutang, para investor adalah price-takers, jika terjadi kebangkrutan maka aset dapat dijual pada harga pasar (market value). 
The Modigliani-Miller Theorem (MM) menggunakan beberapa asumsi: Risiko bisnis perusahaan diukur dengan $\sigma$ EBIT (Standard Deviation Earning Before Interest and Taxes), Investor memiliki pengharapan yang sama tentang EBIT perusahaan di masa mendatang, Saham dan obligasi diperjual belikan di suatu pasar modal yang sempurna, seluruh aliran kas adalah perpetuitas (sama jumlahnya setiap periode hingga waktu tak terhingga). Dengan kata lain, pertumbuhan perusahaan adalah nol atau EBIT selalu sama. Teori MM dengan pajak menyimpulkan bahwa penggunaan hutang akan meningkatkan nilai perusahaan karena biaya bunga hutang adalah biaya yang mengurangi pembayaran pajak.

\section{Faktor-faktor mempengaruhi struktur modal}

Menurut Brigham dan Houston faktorfaktor yang mempengaruhi struktur modal adalah: Stabilitas penjualan, struktur aset, leverage operasi, tingkat pertumbuhan, profitabilitas, pajak, pengendalian, sikap manajemen, sikap pemberi pinjaman dan agen pemberi peringkat, kondisi pasar, kondisi internal perusahaan, fleksibilitas keuangan. maka dalam penelitian ini, menggunakan variable Ukuran Perusahaan, Profitabilitas, Pertumbuhan Aset dan Risiko Bisnis terhadap Struktur Modal sebagai faktor yang mempengaruhi struktur modal perusahaan.

\section{HIPOTESIS}


adalah ukuran perusahaan, profitabilitas, langsung atau melalui perantara (dicatat dan pertumbuhan aset dan risiko bisnis.

1) Ukuran perusahaan (X1) : ukuran perusahaan mengukur besarnya perusahaan diukur dengan rumus sebagai berikut:

Ukuran Perusahaan $=$ Ln Total Aset

2) Profitabilitas (X2) : kemampuan perusahaan dalam memperoleh laba diukur dengan rumus sebagai berikut :

ROI $=\frac{\text { Laba bersih setelah pajak }}{\text { Total aktiva }}$

3) Pertumbuhan aset (X3) : Pertumbuhan aset merupakan selisih antara total aset tahun $\mathrm{t}$ dikurangi dengan total aset tahun sebelumnya(t-1) dibagi dengan total aset tahun sebelumnya (t-1). Pertumbuhan penjualan diukur dengan rumus:

Pertumbuhan aset $=\frac{\text { Total Asset }_{t}-\text { Total Asset }_{t-1}}{\text { Total Asset }_{t-1}}$

4) Risiko bisnis (X4) : Risiko bisnis merupakan stabilitas usaha suatu perusahaan. Pertumbuhan perusahaan diukur dengan rumus:

Risiko Bisnis $=\frac{\sigma \text { EBIT }}{\text { Total Aset }}$

Data yang digunakan dalam penelitian ini adalah data kuantitatif, yaitu data yang diukur dalam skala (angka). Sumber data yang digunakan dalam penelitian ini merupakan data sekunder yaitu data yang diperoleh tidak diolah oleh pihak lain), yang berupa laporan keuangan perusahaan (neraca dan laporan laba rugi) dan diperoleh dari Bursa Efek Indonesia melalui situs resmi Bursa Efek Indonesia (www.idx.co.id)

Pengumpulan data pada penelitian ini dengan metode dokumentasi yaitu dengan mengambil dokumen, jurnal, berkas atau data tertulis yang berhubungan dengan penelitian.

Secara sistematis model yang dikembangkan untuk menguji penelitian ini adalah dengan menggunakan regresi linear berganda. Model tersebut dapat dirumuskan sebagai berikut:

$\mathrm{Y}=\mathrm{b}_{0}+\mathrm{b}_{1} \mathrm{X}_{1}+\mathrm{b}_{2} \mathrm{X}_{2}+\mathrm{b}_{3} \mathrm{X}_{3}+\mathrm{b}_{4} \mathrm{X}_{4}+\mathrm{b}_{5} \mathrm{X}_{5}+\mathrm{e}$ Dimana;

$\mathrm{Y}=$ Struktur Modal

$\mathrm{X}_{1}=$ Ukuran Perusahaan

$\mathrm{X}_{2}=$ Profitabilitas

$\mathrm{X}_{3}=$ PertumbuhanAset

$\mathrm{X}_{4}=$ RisikoBisnis

$\mathrm{b}_{1}-\mathrm{b}_{5}=$ koefisienregresi dari tiap-tiap variabel independen

$\mathrm{b} 0=$ intercept

$\mathrm{e} \quad=$ Standart Error (variabel penganggu)

\section{HASIL DAN PEMBAHASAN}

\section{Analisis Statistik Deskriptif}

Berikut disajikan tabel yang mencantumkan statistik deskriptif keseluruhan variabel penelitian baik variabel dependen maupun independen.

Tabel 1. Analisis Statistik Deskriptif

\begin{tabular}{cccccc}
\hline & $\mathrm{N}$ & Minimum & Maximum & Mean & Std. Deviation \\
\hline $\mathrm{x} 1$ & 30 & 26,48 & 30,39 & 27,7497 & 1,30780
\end{tabular}




\begin{tabular}{llllll} 
x2 & 30 &,- 02 &, 42 &, 1433 &, 14199 \\
x3 & 30 &,- 03 &, 82 &, 1503 &, 17709 \\
x4 & 30 &,- 03 &, 56 &, 2177 &, 19956 \\
Y & 30 &, 03 & 1,38 &, 2030 &, 29333 \\
Valid N (listwise) & 30 & & & & \\
\hline
\end{tabular}

Berdasarkan tabel 1 hasil output deskripsi statistik nilai Harga Saham dengan jumlah N sebanyak 30 nilai Ukuran Perusahaan tertinggi adalah 30,39 sedangkan nilai Ukuran Perusahaan terendah adalah 26,48 dengan nilai rata-rata Ukuran Perusahaan sebesar 27,7497 dengan standar deviasi sebesar 1,30780. Hasil output deskripsi statistik nilai Profitabilitas dengan jumlah $\mathrm{N}$ sebanyak 30 nilai Profitabilitas tertinggi adalah 0,42 sedangkan nilai Profitabilitas terendah adalah $-0,02$ dengan nilai rata-rata Profitabilitas sebesar 0,1433 dengan nilai standard deviasi sebesar 0,14199. Hasil output deskripsi statistik nilai Pertumbuhan Aset dengan jumlah N sebanyak 30 Nilai Pertumbuhan Aset tertinggi adalah 0,82 sedangkan nilai Pertumbuhan Aset terendah adalah -0,03 dengan nilai rata-rata Pertumbuhan Aset sebesar 0,1503 dengan standar deviasi sebesar 0,17709. Hasil output deskripsi statistik nilai Risiko Bisnis dengan jumlah $\mathrm{N}$ sebanyak 30 nilai Risiko Bisnis tertinggi adalah 0,56 sedangkan nilai Risiko Bisnis terendah adalah 0,03 dengan nilai rata-rata risiko bisnis sebesar 0,2177 dengan standar deviasi sebesar 0,199561. Hasil output deskripsi statistik nilai Struktuz. Modal dengan jumlah $\mathrm{N}$ sebanyak 30 nila3. Uji autokolerasi Struktur Modal tertinggi adalah 1,38 sedangkan nilai Struktur Modal terendah adalah 0,03 dengan nilai rata-rata Struktur Modal sebesar 0,2030 dengan standar deviasi sebesar 0,29333.

\section{Uji asumsi klasik}

\section{Uji normalitas}

Adapun hasil uji normalitas adalah sebagai berikut :

\section{Gambar 1}

\section{Hasil uji normalitas}

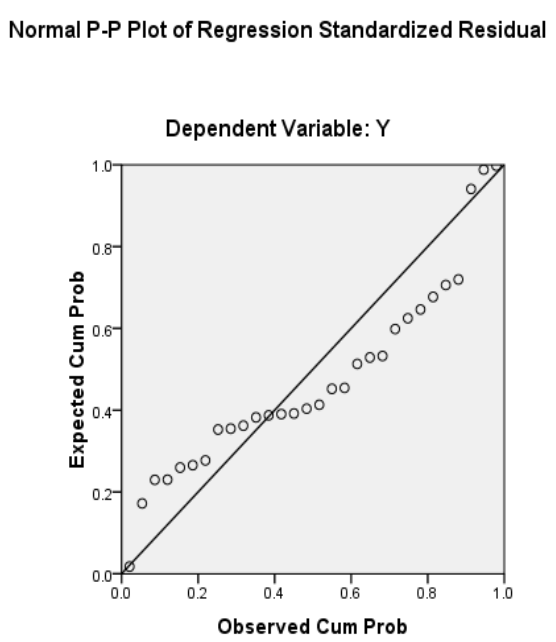

Berdasarkan gambar di atas dapat dilihat hasil output pengujian normalitas bahwa data menyebar disekitar garis diagonal dan mengikuti arah garis diagonal maka model regresi memenuhi uji asumsi normalitas.

Adapun hasil uji autokolerasi adalah sebagai berikut : 
Tabel 2. Hasil Uji autokolerasi

Model Summary

\begin{tabular}{|l|l|}
\hline Model & Durbin-Watson \\
\hline 1 & 1.860 \\
\hline
\end{tabular}

a. Predictors: (Constant), X4, X3, X1, X2

b. Dependent Variable: Y

Berdasarkan Tabel dapat diketahui bahwa nilai Durbin-Watson sebesar 1.860 maka model regresi ini tidak ada autokolerasi karena nilai Durbin-Watson berada diantara -2 sampai +2 .

\section{Uji Multikoliniearitas}

Adapun hasil uji multikoliniearitas adalah sebagai berikut :

Tabel 3. Hasil uji multikoloniearitas

\begin{tabular}{llll}
\hline & \multicolumn{2}{c}{ Collinearity Statistics } \\
& Model & Tolerance & VIF \\
\hline 1 & (Constant) & & \\
& X1 & .171 & 5.859 \\
X2 & .136 & 7.362 \\
& X3 & .871 & 1.148 \\
& X4 & .335 & 2.986 \\
\hline
\end{tabular}

a. Dependent Variable: Y

Berdasarkan Tabel dapat dilihat bahwa hasil perhitungan nilai Tolerance menunjukkan tidak ada variabel yang memiliki nilai tolerance lebih dari 0,1 yang berarti tidak ada korelasi antar variabel independen. Hasil perhitungan Variance Inflation Factor (VIF) juga menunjukkan bahwa tidak ada satupun variabel independen yang memiliki nilai VIF lebih dari 10. Jadi, dapat disimpulkan bahwa tidak ada multikolinieritas antar variabel independen dalam model regresi.

\section{Uji Heteroskedastisitas}

Adapun hasil uji heteroskedastisitas adalah sebagai berikut :

\section{Gambar 2}

Hasil uji heteroskedasitas

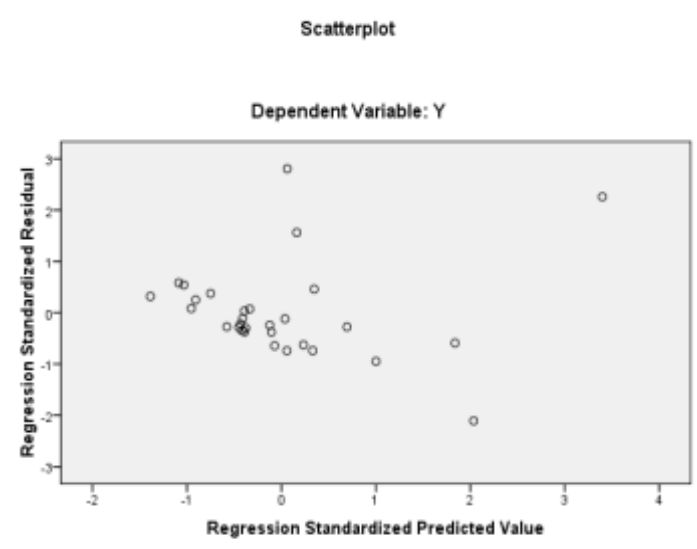

Berdasarkan gambar dapat dilihat bahwa titik-titik menyebar secara acak serta tersebar baik diatas maupun dibawah angka 0 pada sumbu Y. Sehingga dapat disimpulkan bahwa tidak terjadi heterokedastisitas pada model regresi.

\section{Analisis regresi linear berganda}

Pengujian terhadap hipotesis dalam penelitian ini menggunakan analisis regresi berganda. Analisis regresi berganda digunakan untuk menguji pengaruh antara variabel independen yaitu ukuran perusahaan (X1), profitabilitas (X2), dan Pertumbuhan aset (X3) terhadap struktur modal (Y) di BEI sebagai variabel dependen. Adapun hasil uji regresi linier berganda dapat dilihat pada Tabel 4: 
Tabel 4.Analisis regresi linear berganda

Coefficients $^{\mathrm{a}}$

\begin{tabular}{|c|c|c|c|c|c|c|}
\hline & \multirow[t]{2}{*}{ Model } & \multicolumn{2}{|c|}{ Unstandardized Coefficients } & \multirow{2}{*}{$\begin{array}{c}\text { Standardized } \\
\text { Coefficients } \\
\text { Beta }\end{array}$} & \multirow[t]{2}{*}{$\mathrm{t}$} & \multirow[t]{2}{*}{ Sig. } \\
\hline & & B & Std. Error & & & \\
\hline \multirow[t]{5}{*}{1} & (Constant) & 4.254 & 2.275 & & 1.870 & .073 \\
\hline & $\mathrm{X} 1$ & -.157 & .085 & -.699 & -1.840 & .078 \\
\hline & $\mathrm{X} 2$ & 1.663 & .890 & .796 & 1.869 & .073 \\
\hline & X3 & .706 & .282 & .422 & 2.507 & .019 \\
\hline & $\mathrm{X} 4$ & -.212 & .401 & -.143 & -.528 & .602 \\
\hline
\end{tabular}

a. Dependent Variable: Y

Struktur modal $=4,254-0,157$ ukuran

$\mathrm{b}_{3}$ koefisisen regresi pertumbuhan aset perusahaan $+1,663$ profitabilitas $+0,706$ sebesar 0,706 menjelaskan bahwa jika setiap pertumbuhan asset $-0,212$ risiko bisnis kenaikkan Net Profit Margin 1 poin maka akan

Persamaan di atas dapat menurunkan Harga Saham sebesar 0,706 poin.

diinterpretasikan sebagai berikut: Nilai

$\mathrm{b}_{4}$ koefisisen regresi reiko bisnis sebesar konstanta sebesar 4,254 menjelaskan bahwa jika $-0,212$ menjelaskan bahwa jika setiap kenaikkan variabel independen dianggap konstan (variabel Risiko Bisnis 1 poin maka akan menurunkan independen=0), maka nilai variabel Harga Saham sebesar -0,212 poin. dependennya, yaitu Struktur Modal adalah sebesar 4,254 poin.

Variabel penganggu (standar error) dalam penelitian ini sebesar 2,275 poin.

$b_{1}$ koefisisen regresi ukuran perusahaan sebesar -0,157 menjelaskan bahwa jika setiap kenaikkan ukuran perusahaan 1 poin maka akan menurunkan ukuran perusahaan sebesar $-0,157$ poin.

$\mathrm{b}_{2}$ koefisisen regresi profitabilitas sebesar 1,663 menjelaskan bahwa jika setiap kenaikkan profitabilitas 1 poin maka akan menurunkan Harga Saham sebesar 1,663 poin.

\section{Uji hipotesis}

\section{Uji F (Uji Simultan)}

Uji $\mathrm{F}$ dilakukan untuk melihat pengaruh variabel independen secara bersama-sama terhadap variabel dependen. Hasil uji F dapat dilihat pada Tabel 5 berikut ini.

Tabel 5. Hasil uji F 


\begin{tabular}{llccccc} 
& Model & Sum of Squares & df & Mean Square & F & Sig. \\
\hline 1 & Regression & .956 & 4 & .239 & 3.882 & $.014^{\mathrm{a}}$ \\
Residual & 1.539 & 25 & .062 & & \\
Total & 2.495 & 29 & & & \\
\hline
\end{tabular}

a. Predictors: (Constant), X4, X3, X1, X2

b. Dependent Variable: Y

Berdasarkan Tabel 5 dapat dilihat bahwa variabel independen pertumbuhan aset, ukuran perusahaan, profitabilitas, risiko bisnis berpengaruh secara simultan terhadap struktur modal karena nilai signifikan sebesar 0,014 dan lebih kecil dari pada nilai signifikan yaitu $5 \%$.

\section{Uji t (Uji Parsial)}

\section{Pengaruh pertumbuhan aset terhadap} struktur modal

Variabel Ukuran Perusahaan

berpengaruh tidak signifikan terhadap struktur modal pada perusahaan kosmetik dan keperluan rumah tangga. Hal tersebut dibuktikan dengan nilai Koefisisen regresi ukuran perusahaan sebesar -0,157 selain itu, nilai profitabilitas signifikansi sebesar 0.078 juga menunjukkan nilai yang lebih besar dari nilai yang telah ditentukan pada tingkat $5 \%$ yaitu sebesar 0.05 $(0.078>0.05)$.

Hasil penelitian ini sama dengan penelitian yang dilakukan oleh Setiawan pada tahun 2011 dengan judul "pengaruh struktur aktiva, ukuran perusahaan, profitabilitas dan risiko bisnis terhadap struktur modal perusahaan". Yang memiliki variabel Struktur modal, struktur aktiva, ukuran perusahaan, profitabilitas dan risiko bisnis. Hasil dari penelitian ini menunjukan bahwa ukuran perusahaan tidak berpengaruh terhadap struktur modal.

Hasil penelitian ini berbeda dengan yang penelitian yang dilakukan oleh Wahyuningsih et al. Pada tahun 2012 dengan judul "analisis variabel- variabel yang mempengaruhi struktur modal" (studi empiris pada Perusahaan Makanan dan Minuman yang terdaftar di bursa efek Jakarta) memiliki variabel struktur modal, struktur aktiva, profitabilitas, ukuran perusahaan, pertumbuhan penjualan, operating leverage, dan investment opportunity. Hasil dari penelitian ini ukuran perusahaan berpengaruh secara signifikan terhadap struktur modal.

Hasil penlitian ini sama juga dengan penelitian yang dilakukan oleh Khusnul pada tahun 2012 yang berjudul "analisis variabelvariabel yang mempengaruhi struktur modal" yang memiliki variabel struktur modal, ukuran perusahaan, pertumbuhan dan penjualan dan rating premium. Hasil dari penelitian ini adalah ukuran perusahaan tidak berpengaruh signifikan terhadap struktur modal. 
Pengaruh profitabilitas terhadap struktur modal

Variabel profitabilitas tidak berpengaruh terhadap struktur modal pada perusahaan Kosmetik dan Keperluan Rumah Tangga. Hal tersebut dibuktikan dengan nilai Koefisisen regresi profitabilitas sebesar 1.663 selain itu, nilai profitabilitas signifikansi sebesar 0.073 juga menunjukkan nilai yang lebih besar dari nilai yang telah ditentukan pada tingkat 5\% yaitu sebesar $0.05(0.073>0.05)$.

Hasil penelitian ini sama dengan penelitian yang dilakukan oleh Setiawan pada tahun 2011 dengan judul "pengaruh struktur aktiva, ukuran perusahaan, profitabilitas dan risiko bisnis terhadap struktur modal perusahaan”. Yang memiliki variabel Struktur modal, struktur aktiva, ukuran perusahaan, profitabilitas dan risiko bisnis. Hasil dari penelitian ini menunjukan bahwa profitabilitas tidak berpengaruh terhadap struktur modal.

Hasil penelitian ini berbeda dengan penelitian yang dilakukan oleh Wahyuningsih et al. Pada tahun 2012 dengan judul "analisis variabel-variabel yang mempengaruhi struktur modal" (studi empiris pada Perusahaan Makanan dan Minuman yang terdaftar di bursa efek Jakarta) memiliki variabel struktur modal, struktur aktiva, profitabilitas, ukuran perusahaan, pertumbuhan penjualan, operating leverage, dan investment opportunity. Hasil dari penelitian ini profitabilitas berpengaruh secara signifikan terhadap struktur modal.
Hasil penelitian ini sama penelitian ini dilakukan oleh Khusnul pada tahun 2012 yang berjudul "analisis pengaruh capital expenditure, sales growth, profitabilitas, size, dan rating premium struktur modal" yang memiliki variabel struktur modal, ukuran perusahaan, pertumbuhan dan penjualan dan rating premium. Hasil dari penelitian ini adalah profitabilitas tidak berpengaruh signifikan terhadap struktur modal.

\section{Pengaruh Pertumbuhan Aset terhadap}

\section{Struktur Modal}

Variabel Pertumbuhan Aset berpengaruh signifikan terhadap Struktur Modal pada perusahaan Kosmetik dan Keperluan Rumah Tangga. Hal tersebut dibuktikan dengan nilai Koefisisen regresi Pertumbuhan Aset sebesar 0,706 selain itu, nilai profitabilitas signifikansi sebesar 0.019 juga menunjukkan nilai yang lebih besar dari nilai yang telah ditentukan pada tingkat $5 \%$ yaitu sebesar $0.05(0.019>0.05)$.

Hasil penelitian ini sama dengan penelitian yang dilakukan oleh Wahyuningsih et al.(2012) menyatakan bahwa variabel struktur modal, struktur aktiva, profitabilitas, ukuran perusahaan, pertumbuhan penjualan, operating leverage, dan investment opportunity. pertumbuhan penjualan berpengaruh secara signifikan terhadap struktur modal.

Hasil penelitian ini sama dengan penelitian ini dilakukan oleh Khusnul (2012)menyatakanbahwavariabel struktur modal, ukuran perusahaan, pertumbuhan dan 
penjualan dan rating premium. Hasil dari penelitian ini adalah pertumbuhan dan penjulan berpengaruh signifikan.

\section{Pengaruh Risiko Bisnis terhadap Struktur} Modal

Variabel Risiko Bisnis berpengaruh tidak signifikan terhadap Struktur Modal pada perusahaan Kosmetik dan Keperluan Rumah Tangga. Hal tersebut dibuktikan dengan nilai Koefisisen regresi Risiko Bisnis sebesar - selain itu, nilai profitabilitas signifikansi sebesar 0,226 juga menunjukkan nilai yang lebih besar dari nilai yang telah ditentukan pada tingkat 5\% yaitu sebesar $0.05(0.226>0.05)$.

Hasil Penelitian ini berbeda dengan hasil penelitian yang dilakukan oleh Setiawan (2011) menyatakan bahwa struktur aktiva dan risiko bisnis berpengaruh secara positif dan signifikan terhadap struktur modal, sedangakan ukuran perusahaan dan profitabilitas tidak berpengaruh terhadap struktur modal.

Pengaruh Ukuran Perusahaan, Profitabiitas, Pertumbuhan Aset dan Risiko Bisnis terhadap Struktur Modal.

Variabel Ukuran

Perusahaan,

Profitabiitas, Pertumbuhan Aset dan Risiko Bisnis secara simultan berpengaruh signifikan terhadap Struktur Modal. hasil tersebut bisa dilihat dari nilai profitabilitas signifikansi sebesar 0,014 juga menunjukkan nilai yang lebih kecil dari nilai yang telah ditentukan pada tingkat $5 \%$ yaitu sebesar $0.05(0.014<0.05)$.

$$
\text { Berdasarkan hasil penelitian }
$$
menyimpulkan bahwa hasil penelitian ini sejalan dengan hipotesis. Menurut agency theory yang dikemukakan oleh Michael C. Jensen dan William H. Meckling. Menurut pendekatan ini, struktur modal disusun sedemikian rupa untuk mengurangi konflik antar berbagai kelompok kepentingan (Hanafi, 2003). Penyusunan struktur modal menyesuaikan dengan kondisi perusahaan, apakah hutang perusahaan dalam kondisi yang menyebabkan perusahaan menemui financial distress, atau kondisi profit perusahaan yang sedang dalam keadaan yang sangat baik, atau kondisi beban pajak perusahaan yang bisa dikatakan tinggi atau masih bisa untuk terus penambahan modal sendiri, atau juga perusahaan dalam kondisi yang prima sehingga membutuhkan aset dalam jumlah yang sangat besar yang membutuhkan hutang untuk penambahan modalnya. Semua hal dapat dilihat berdasar variabel Ukuran Perusahaan, Profitabilitas, Pertumbuhan Aset dan Risiko Bisnis. Dengan demikian dapat disimpulkan bahwa Ukuran Perusahaan, Profitabilitas, Pertumbuhan Aset dan Risiko Bisnis berpengaruh terhadap Struktur Modal.

\section{SIMPULAN}

Berdasarkan hasil penelitian ini maka dapat disimpulkan bahwa Ukuran Perusahaan 
berpengaruh tidak signifikan terhadap Struktur

Modal. Ini berarti penambahan ukuran perusaaan akan menaikkan Struktur Modal dan penurunan ukuran perusahaan akan menurunkan Struktur Modal namun tidak signifikan. Profitabilitas berpengaruh tidak signifikan terhadap Struktur Modal Ini berarti penambahan profitabilitas akan menaikkan Struktur Modal dan penurunan profitabilitas akan menurunkan Struktur Modal namun tidak signifikan. Pertumbuhan Aset berpengaruh signifikan terhadap Struktur Modal. Ini berarti penambahan pertumbuhan aset akan menurunkan Struktur Modal dan pertumbuhan aset akan menaikkan Struktur Modal secara signifikan. Risiko bisnis berpengaruh tidak signifikan terhadap Struktur Modal. Ini berarti penambahan risiko bisnis akan menaikkan Struktur Modal dan penurunan risiko bisnisakan menurunkan Struktur Modal namun tidak signifikan. Ukuran perusahaan, profitabilitas, pertumbuhan aset dan risiko bisnis secara simultan berpengaruh signifikan terhadap Struktur Modal. Ini berarti jika nilai ukuran perusahaan, profitabilitas, pertumbuhan aset dan risiko bisnis naik dapat menaikkan Struktur Modal dan sebaliknya.

Keterbatasan pada penelitian ini adalah perusahaan yang diteliti hanya ada 6 (enam) perusahaan, sebaiknya peneliti mengambil perusahaan lain agar hasil yang didapatkan lebih baik.

\section{SARAN}

Saran pada penelitian ini adalah para peneliti selanjutnya disarankan untuk menambah variabel yang akan dipakai dalam penelitian agar hasil yang diperoleh lebih akurat dan memiliki cakupan yang lebih luas. Selain itu juga para peneliti selanjutnya sebaiknya menggunakan sektor usaha penelitian selain perusahaan manufaktur untuk mengetahui sektor usaha mana yang memiliki kondisi kinerja keuangan yang lebih baik.

\section{DAFTAR PUSTAKA}

Bambang, Riyanto. 2001. Dasar-dasar Pembelajaran Perusahaan. Edisi 3. Yogyakarta : BPFE.

Brealey, Richard A Stewart C, Myers. Alan J, Marcus. 2001. Fundamentals of Corporate Finance. Third Edition. Singapore: Mc Graw-Hill.

Brigham, dan Houston. 2004, Dasar-dasar Manajemen Keuangan. Edisi Kesepuluh, Buku Dua. Jakarta : Salemba Empat.

Ghozali, Imam. Aplikasi Analisis Mutivariate dengan Program SPSS. Semarang : Badan Penerbit- Undip.

Hanafi, Mamduh H. Halim, 2003. Analisis laporan keuangan. Yogyakarta : UPPAMP YKPN.

Horgren, dan Bamber. 2007. Akuntansi Edisi Keenam Jilid satu. Terjemhaan Oleh Utama, S. S. Jakarta : Indeks.

Husnan, Suad. 2008. Manajemen Keuangan: Teori dan Penerapan. Edisi 4. Yogyakarta: BPFE.

Jensen, M. C and Meckling, W.H. 1976. Theory of the Firm : Managerial Behavior,Agency Costs and Ownership Structure. Journal of Financial Economics, Oktober, 1976, V. 3, 
No. 4, pp. 305-360. Avalaible from:http://papers.ssrn.com.

Khusnul, Fakthiatur. 2012. "Analisis Pengaruh Capital Expenditure, Sales Growth, Profitability, Size, dan Rating Premium terhadap Struktur Modal (Studi Perbandingan Pada Perusahaan Food and Beverage dan Automotive and alied Product Periode 2006-2011)". Skripsi. Semarang : Universitas Diponegoro.

Nugroho, Asih Suko. 2006. “Analisis Faktorfaktor yang Mempengaruhi Struktur Modal Perusahaan Properti yang GoPublic Di Bursa Efek Jakarta Untuk Periode Tahun 2014-2004". Tesis. Semarang : Universitas Diponegoro.

Saidi. 2004. Faktor-faktor yang mempengaruhi struktur Modal pada Perusahaan Manufaktur Go Public di BEJ. Jurnal, hlm 190-203.

Seftianne. 2011. "faktor-faktor yang Mempengaruhi struktur Modal pada Perusahaan Publik Sektor Manufaktur”. Jurnal. Jakarta : STIE Trisakti.

Setiawan. 2011. "Pengaruh Struktur Aktiva, Ukuran Perusahaan, Profitabilitas dan Risiko Bisnis terhadap Struktur Modal. Skripsi.Semarang: Univesitas Diponegoro.

Sugiono. 2014. Metode Penelitian Kuantitatif Kualitatif dan $R \& D$. Bandung : Alfabeta.

Supriyanto, Eko dan Falikhatun. 2008. "Analisis Pengaruh Likuiditas dan Profitabilitas Terhadap Struktur Modal pada Perusahaan Food and Beverage Di Bursa Efek Indonesia". Dalam Jurnal Bisnis dan Akuntansi, Vol. 10 No. 1. Hal 13-22 Surakarta: Universitas Sebelas Maret.

Van Horne dan Wachowichz. 2013. Fundamental of Financial Management. Jakarta : Salemba Empat.

Wahyuningsih, et al. 2012. “Analisis Varabelvariabel yang Mempengaruhi Struktur Modal (Study Empiris pada Perusahaan Makanan dan Minuman yang Terdaftar di Bursa Efek Jakarta)”. Tesis. Malang : Universitas Brawijaya.
Weston dan Brigham. 2014. Dasar-dasar Manajemen Keuangan. Cetakan kelima. Bandung : Erlangga.

Yovin dan Suryantini. 2012. "Faktor-faktor yang Berpengaruh Terhadap Struktur Modal pada Perusahaan Foods and Beverages yang Terdaftar Di Bursa Efek Indonesia". Tesis. Denpasar: Universitas Udayana. 